\title{
Idræt er mere end gymnastik og sport
}

\author{
af Jørn Hansen og Niels Kayser Nielsen
}

Fremstillingerne i Idrætshistorisk Årbog har i en årrække været relateret til forskellige temaer. Fodboldhistorie, lokalhistorie, gymnastikhistorie, de olympiske lege, instruktør- og lederopfattelsen i hovedorganisationerne samt, som det var tilfældet sidste år, kropskultur og identitet. Også denne årbog er forsøgt relateret til et tema, men hvor de andre års fremstillinger direkte har forbundet sig med temaerne, er dette ikke tilfældet $i$ denne årbog. Artiklerne knytter sig i år i stedet afgrænsende til temaet. Artiklernes fællesnævner er, at de alle beskæftiger sig med emner, der i traditionel forstand hverken er gymnastik eller sport.

Flere af artiklerne har selvfølgelig berøringsflader med gymnastikken eller sporten, men de behandler bevægelsesmønstre der enten kan opfattes som pegende frem imod gymnastikken og sporten eller væk fra gymnastikken og sporten.

Selvfølgelig er begreberne gymnastik og sport ikke entydige, men reelt har den folkelige gymnastik og sporten hver deres hovedorganisation(er). Endvidere er der i $1 \varnothing$ bet af de sidste 10 år i den idrætshistoriske litteratur om den folkelige gymnastik og sporten efterhånden opstået en form for konsensus om disse begreber.

Dansk Idrætshistorisk Forening Krop og Kultur har aktivt medvirket til udfomningen af denne konsensus - og kan vel med tilfredshed bryste sig heraf. På den anden side kan man lidt pro- vokerende stille det spørgsmål, om ikke de reale bevægelser har gjort det lettere for idrætsforskerne. Er det ikke nemmere begrebsligt at afgrænse foreteelser og bevægelser, der har udlevet deres rolle. Bliver historikerne ikke først rigtig kloge på noget, der er sket? Er det ikke først, når en verden går under, at den bliver »værdig « for historikere at beskæftige sig med, således at tabsfornemmelsen er historikerens og idrætshistorikerens vilkår?

På indeværende tidspunkt kan vi ikke vide, om vor fornemmelse af, at den folkelige gymnastik og sporten er ved at være fortidige, er korrekt, men vi kan forholde os til nogle af de tendenser, der er inden for bevægelserne. Et af de omdiskuterede spørgsmål siden lands-stævnet i Horsens sidste år har været: hvad er indholdet i den folkelige idræt? Man kan måske også spørge, hvor er den folkelige idræt? Spørgsmålet er ikke blevet besvaret, men der skal være landsstævne i Svendborg i 1992 under et hovedforbund (?). Er bestræbelserne på at sammenlægge DDSG\&I og DDGU en manifestation for den folkelige idræt, eller er der tale om et krisetegn?

Fodbolden og håndbolden mister medlemmer, men badminton, tennis og andre sportsgrene oplever en medlemsfremgang. Generelt kan sporten da ikke være på retur. Og dog: sker der ikke en klar spaltning inden for den gamle sportsbevægelse? Elite- og showsport går mere og mere op $\mathrm{i}$ en 
"større enhed «, på bredde-idræts området viser det sig at hovedparten af sportsudøverne over 16 år træner og motionerer, men ikke deltager i konkurrencer (!), jvf. hertil undersøgelsen om sport og motion i T. Fridbergs »Danskerne og kulturen« (1989). Hvornår kan vi i dag tale om breddeidræt, hvornår bør vi tale om sundhed og trivsel?

Afklaringen af hvad der kendetegner den folkelige gymnastik og sportsbevægelsen rejser således en række nye spørgsmål og fører til en interesse for, hvad der gik forud for og hvad der peger væk fra den folkelige gymnastik og sporten.

Hovedparten af artiklerne i Årbogen beskæftiger sig med, hvad der gik forud for gymnastikken og sporten. Tre af disse relaterer sig til hofkulturen. Under overskriften Legems $\varnothing$ velser og dansk hofkultur har vi valgt at genoptrykke afsnittet om ridderspil, dystridt, fægteskole og slagsmål fra kapitel 3. Almindelige forlystelser $i$ bind 6 af Troels Lunds $\gg$ Dagligliv i Norden i det 16de århundrede« (1903). Ole Worm skildrer i Boldhuse i Danmark - dansk sportsbyggeri $i 1600$ \& 1700-tallet det tidligste »tennisspils « korte historie ved det danske hof. Monna Dithmers artikel Hofballet og barokke passioner om dans med anstand relaterer sig som den sidste til hofkulturen.

Forholdet mellem tidligere tiders legemskultur og den folkelige gymnastik og sport kan altid diskuteres ud fra en brud-kontinuitets diskurs. I artiklen Kunsten at svave søger Else Trangbæk efter en forbindelseslinie mellem akrobatik og gymnastik.

I diskussionen om gymnastikkens og sportens afgrænsning har flere prøvet at reaktualisere legen. Både $i$ form af en opdyrkning af gamle lege samt i en diskussion af legens status i den moderne idræt. I Idrat og leg forfølger Jørn Møller i et historisk rids fra Gutsmuts til F. Knudsen de overvejelser, som førte til at lege i pædagogisk $\emptyset$ jemed blev til idræt. Interessant er det, at vi i dag ca. 100 år efter at F. Knudsen startede sit projekt med indsamling af lege påny oplever en kulturhistorisk og pædagogisk interesse for "gamle « lege. Er det modernitetens fuldendelse eller er det et postmoderne opbrud?

Hvad er sport og hvad er bevægelseslege? I artiklen Bevagelseslege tager Søren Damkjær ud fra en semiotisk - tegnlæsende - indfaldsvinkel kritisk stilling til det konfiguratioanbegreb, der især er blevet anvendt til at karakterisere sporten. - Er bevægelseslegene ikke så forskellige, at der $\emptyset$ ves vold på realiteterne, når de sættes på ét begreb? Har vi her at gøre med en anden vej ud af sporten - andre fagtraditioner end historikerens påpeger ofte ved et emnes historiske endeligt, at emnet kun har eksisteret som en fiktion.

Børn leger aldrig mere, udtales der ofte af idrætsstuderende, der ikke selv har børn. Der leges ikke mere i idrætten udtaler idrætspædagogerne. Med udgangspunkt i Huizingas legebegreb undersøger Verner Møller i artiklen Den kulturgenererende leg og idrattens trefoldighed legens status i såvel kulturen son idrætskulturen. Problemet er ikke om legen generelt er gået tabt, snarere hvorledes legen i dag tager sig ud.

I tiden hvor gymnastikken og sporten har været dominerende har legemskulturen også haft andre former. Dansen 
har bortset fra sportsdansen været et område uden for den etablerede idræt. Arbejderidrætten er ofte blevet tænkt som et område uden for den etablerede idræt. I artiklen om Fagenes Fest beskriver Jørn Hansen, hvorledes dette fænomen for en periode fremstod som et reelt arbejderalternativ til sporten, hvad enten denne - sporten - var tænkt organiseret bredt af Dansk Idræts-Forbund eller udelukkende var et arbejderanliggende.

En vej væk fra sporten er elitesportens sammensmeltning med showsporten. I amerikansk wrestling er forbindelseslinien til sportsverdenen kun karikerende til stede. I artiklen Wrestling, et studie i $\emptyset$ rkenvandring fortolker Finn Wiedemann dette fænomens egen iscenesættelse og derigennem totale afklædning af de »gamle« europæiske idrætsidealer, som de var i gymnastikken og sporten. De fleste steder har elitesporten dog endnu ikke smidt tøjet, man forsøger i stedet at sætte idealerne og showet lige højt.

Hver generation skriver sin historie. En ny orientering inden for idrætsbevægelsen fører til en ny orientering inden for den idrætshistoriske forskning - artiklerne i dette nummer afspejler til en vis grad dette. I en yderst radikal udgave forholder Henning Eichberg sig til denne problemstilling i artiklen Kroppen som basis. Paradigmeskift $i$ sportens kultursociologi. Sammenhængen mellem aktuel orienteringsretning og historiestudiets interessefelt relativerer eller umuliggør (?) en hvilken som helst diskussion af sportens eller for den sags skyld legemskulturens oprindelse. En overgang søgte sportshistorikerne efter det første løb eller det første spydkast - den tidligste form for sport var jagt, krig eller et ritual. I det eventuelle opbrud fra gymnastikken og sporten bliver andre historiske begivenheder eller antropologiske billeder interessante - som provokations- og anskuelsesbillede bruger Henning Eichberg opdagelsen af, at chimpanser danser.

Som allerede nævnt ved vi ikke, om vi har ret i vor antagelse af, at den folkelige gymnastik og sporten reelt er ved at blive historiske. På det kulturelle område er det dog efterhånden ved at være en banalitet at tale om opbrudstendenser. Det vil således til en vis grad være naturligt at anvende dette års negativt afgrænsende tematisering til - i hvert fald for en periode - helt at forlade temastrukturen for Idrætshistorisk Årbog. Dette gøres ikke, fordi vi mener, at gymnastikkens og sportens historie - eller for den sags skyld andre af de indledningsvist nævnte temaers historie er udforsket. Tværtimod er der stadig en mængde ubelyste områder inden for de næunte emner, men en fastholdelse af en temastruktur ville kunne blokere for diskussionen af disse emner.

Dertil kommer - og det er absolut det vigtigste og det mest positive - at institutionaliseringen af den idrætshistoriske forskning begynder at sætte sine spor blandt studerende og nyuddannede. Opprioriteringen af det humanistisk-samfundsvidenskabelige område inden for idrætsforskningen har betydet, at der produceres eksamensopgaver og specialer, der i bearbejdet form vil være velegnet til offentligg ørelse en temastruktur må ikke blokere for disse artikler in spe. 
